University of Nebraska - Lincoln

DigitalCommons@University of Nebraska - Lincoln

3-1-2004

\title{
Tillage and Rotation Interactions for Corn and Soybean Grain Yield as Affected by Precipitation and Air Temperature
}

Wally Wilhelm

University of Nebraska-Lincoln, wally.wilhelm@ars.usda.gov

Charles S. Wortmann

University of Nebraska-Lincoln, cwortmann2@unl.edu

Follow this and additional works at: https://digitalcommons.unl.edu/usdaarsfacpub

Part of the Agricultural Science Commons

Wilhelm, Wally and Wortmann, Charles S., "Tillage and Rotation Interactions for Corn and Soybean Grain Yield as Affected by Precipitation and Air Temperature" (2004). Publications from USDA-ARS / UNL Faculty. 66.

https://digitalcommons.unl.edu/usdaarsfacpub/66

This Article is brought to you for free and open access by the U.S. Department of Agriculture: Agricultural Research Service, Lincoln, Nebraska at DigitalCommons@University of Nebraska - Lincoln. It has been accepted for inclusion in Publications from USDA-ARS / UNL Faculty by an authorized administrator of DigitalCommons@University of Nebraska - Lincoln. 


\title{
Tillage and Rotation Interactions for Corn and Soybean Grain Yield as Affected by Precipitation and Air Temperature
}

\author{
W. W. Wilhelm and Charles S. Wortmann*
}

\begin{abstract}
Reduced tillage, including no-till, and crop rotation are common practices for corn (Zea mays $\mathrm{L}_{\text {.) }}$ and soybean [Glycine max (L.) Merr.] production in the Midwest. Benefits of no-till vary with latitude and cropping system. This study was conducted to evaluate the influence of seasonal temperature and precipitation on the effects of primary tillage (plow, disk, chisel, subsoil, ridge-till, and no-till) and rotated and continuous corn and soybean production under rainfed conditions over $16 \mathrm{yr}$ in southeastern Nebraska. Corn and soybean produced less grain with greater summer temperatures. Corn yield increased with less spring and more summer rainfall. Tillage and rotation practices affected corn grain yield; but only rotation affected soybean yield. Corn produced less grain with no-till than with plow. The tillage $\times$ year interaction was significant for both crops; the yield advantage for plow was less during seasons with warmer springs. Soybean grain yield was less responsive to favorable environments with the chisel than other tillage treatments. Grain yield was greater with rotation than continuous cropping for both corn (7.10 vs. 5.83 $\mathrm{Mg} \mathrm{ha}^{-1}$ ) and soybean ( $2.57 \mathrm{vs.} 2.35 \mathrm{Mg} \mathrm{ha}^{-1}$ ). The benefit of rotation in terms of grain yield was greatest for corn during years with cool springs. The benefit of rotation for soybean grain yield did not vary with weather conditions. Seasonal temperature and rainfall patterns influenced the effects of tillage and rotation on corn yield. In contrast, for soybean, only the pattern of temperature influenced the effect of tillage on yield.
\end{abstract}

$\mathrm{N}$ O-TILL AND RIDGE-TILL planting are established conservation tillage systems in the Midwest. The area planted without preplant tillage in the United States is estimated to be $21 \times 10^{6} \mathrm{ha} \mathrm{yr}^{-1}$ ( $38 \%$ of U.S. cropland; Conserv. Technol. Inf. Cent., 2000). The primary reason given by crop producers in Nebraska for practicing conservation tillage is reduced costs (McCabe, 2002). Other important reasons given for adopting conservation tillage were soil protection, water conservation, increased yield, and increased profit.

Rotation of corn and soybean is often preferred to continuous cropping with either crop because the rotation produces greater grain yield of both crops (Peterson and Varvel, 1989a, 1989b; Varvel, 1994; West et al., 1996). Input costs are often less with rotation (Foltz et al., 1995), with less $\mathrm{N}$ fertilizer needed for the corn-soybean rotation compared with continuous corn. A corn-soybean

W.W. Wilhelm, USDA-ARS, 117 Keim Hall, Univ. of Nebraska, Lincoln, NE 68583-0934; and C.S. Wortmann, Dep. of Agron. and Hortic., Univ. of Nebraska, Lincoln, NE 68583-0915. Joint contribution the USDA-ARS and the Univ. of Nebraska, Agric. Res. Div., Lincoln, NE 68583, Journal Series no. 13950. Product names are given solely for the benefit of the reader and are not meant to constitute a recommendation or warranty by USDA's Agricultural Research Service or the Agricultural Research Division of the University of Nebraska. Received11 Dec. 2002.*Corresponding author (cwortmann2@unl.edu).

Published in Agron. J. 96:425-432 (2004).

(C) American Society of Agronomy

677 S. Segoe Rd., Madison, WI 53711 USA rotation is also more effective in preventing deep leaching of nitrate $\mathrm{N}$ than continuous corn (Katupitiya et al., 1997; Varvel and Peterson, 1990). Reduced stress from pests may be one of the reasons for improved yield with crop rotations (Boosalis and Doupnik, 1976).

Reports on the effects of tillage and crop sequence (rotation) on grain yield of both corn and soybean in the Corn Belt vary considerably. Planting corn and soybean without tillage results in increased yield in some environments but less in other environments. Several researchers have shown that the crop rotation benefit is greater with no-till than with tillage (Griffith et al., 1988; Lund et al., 1993). The summary statement that yield increase with no-till compared with tillage is less likely for continuous corn compared with corn in rotation on poorly drained soils in northern latitudes is supported by results of tillage studies conducted on both poorly and well-drained soils in Ohio (Dick et al., 1991) and on poorly drained soils in Illinois (McIsaac et al., 1990) and Iowa (Brown et al., 1989).

On well-drained soils, crop yields were less with notill than with tillage in studies conducted in Iowa (Chase and Duffy, 1991), Indiana (West et al., 1996), northwestern Iowa (Bakhsh et al., 2000), and Wisconsin (Adee et al., 1994; Lund et al., 1993). In contrast, yields were greater with no-till in Nebraska (Dickey et al., 1994) and Ohio (Dick et al., 1991). To further complicate the issue, no differences in yield between no-till and tilled treatments were reported for studies conducted in Michigan (Hesterman et al., 1988) and Wisconsin (Al-Darby and Lowery, 1986; Lund et al., 1993). Corn and/or soybean yield was greater with ridge-till than with no-till in Indiana (West et al., 1996) but not different in Nebraska (Cahoon et al., 1999) and Wisconsin (Al-Darby and Lowery, 1986). Griffith and Wollenhaupt (1994) summarized these differing results by stating that the probability of a corn yield increase with no-till is greatest on welldrained soil when grown in rotation and in southern latitudes of the United States. The objective of this research is to evaluate the influence of seasonal temperature and precipitation on tillage and crop sequence (rotation) effects on the grain yield responses in corn and soybean production.

\section{MATERIALS AND METHODS}

This field research was conducted at the Rogers Memorial Farm over 16 yr (1986-2001) on a silty clay loam soil (deep, moderately well-drained upland Sharpsburg soil formed in loess; fine, smectitic, mesic Typic Argiudolls) near Lincoln, $\mathrm{NE}$, under natural rainfall conditions.

The experiment was designed as a randomized complete block (six blocks) with a split-plot arrangement of treatments. Tillage treatments were assigned to whole plots and included chisel plow (chisel), tandom disk (disk), moldboard plow (plow), 
no-till, ridge-till, and subsoil tillage. Subplot treatments were continuous corn, continuous soybean, soybean-corn, and corn-soybean so that each phase of all crop sequences was presented each year. Whole plots were 18.3 (twenty-four $0.76-\mathrm{m}$ rows) by $22.9 \mathrm{~m}$. Subplots were 4.6 (six $0.76-\mathrm{m}$ rows) by $22.9 \mathrm{~m}$.

After grain harvest from 1986 through 1999, corn stover was chopped on the chisel, plow, and subsoil treatments. These treatments were then tilled. Depth of tillage was approximately $25 \mathrm{~cm}$ for the chisel and plow treatments and $36 \mathrm{~cm}$ for the subsoil treatment. The straight chisel shanks with straight points were at a $25-\mathrm{cm}$ spacing. The subsoil implement (Blujet Subtiller1, Thurston Manufacturing Co., Thurston, NE) was equipped with standard shanks and fall-till points at a 76- $\mathrm{cm}$ spacing and positioned to operate between the planted rows. Residue was chopped in spring for the disk, no-till, and ridge-till treatments. Depth of tillage for the disk treatment was approximately $10 \mathrm{~cm}$. All tilled treatments were disked to $<10 \mathrm{~cm}$ depth before planting (including the disk treatment, which was disked a second time). No primary or secondary preplant tillage operations were performed on the no-till or ridge-till treatments. Corn was planted in the first week of May as weather and soil conditions allowed, except in 1996 when planting was delayed, because of wet soil, until 26 May. Soybean planting also depended on weather and soil conditions but was usually delayed by 1 wk (by 2 wk in 1989 when soybean was planted on 17 May) after corn was planted. All crops were planted in $76-\mathrm{cm}$ rows with a planter equipped with six Kinze Precision Placement Style A row units (Kinze Manufacturing Co., Williamsburg, IA) with double-disk openers. Scalloped trash disks were adjusted to remove 3 to $5 \mathrm{~cm}$ of soil from the top of the ridge in the ridge-till treatment. In the no-till treatment, the trash disks were adjusted to move 0 to $2 \mathrm{~cm}$ of soil and the old crown from the row. All treatments, except no-till, were cultivated between the V5 and V8 growth stages (Ritchie et al., 1986) for corn and about V5 growth stage (Ritchie et al., 1996) for soybean. At this time, or within $2 \mathrm{wk}$, ridges were formed in the ridge-till treatment. Both cultivating and ridging were done with a Buffalo row-crop cultivator (Fleischer Manufacturing Co., Columbus, NE). Since 1999, stalks were chopped on all treatments, and all of the tilled treatments (including disk) were tilled in fall after grain harvest. All tilled treatments were disked lightly before planting.

Other cultural practices were similar to those used by local producers. Currently recommended hybrids of corn and varieties of soybean were planted each year. Planting population for corn ranged from 40000 kernels $\mathrm{ha}^{-1}$ in the early years of the study to 58000 kernels ha ${ }^{-1}$ in more recent years (since 1996). Soybean was planted at rates between 250000 and 375000 seeds ha ${ }^{-1}$. Insecticides (which varied over years) were applied to corn at planting according to label procedures to reduce rootworm damage. For both corn and soybean, a combination of pre- and postemergence herbicides (again products varied over the years of study), cultivation, and hand weeding were used to control weeds. Roundup Ready varieties of soybean have been planted since 1998. Roundup Ready hybrids of corn have been planted since 1999. Nitrogen was broadcast to corn at $113 \mathrm{~kg} \mathrm{~N} \mathrm{ha}^{-1}$ as ammonium nitrate at about the V3 growth stage. Other plant nutrients were within optimum levels for corn and soybean production.

Corn and soybean were harvested after reaching physiological maturity. Before 1998, yield was determined by handcollecting all ears from an area of at least $9.3 \mathrm{~m}^{2}$ within each corn plot. Grain was removed from the ears, weighed, and sampled for water content determination. During this period, soybean yield was determined by collecting all plants from an area of at least $4.6 \mathrm{~m}^{2}$. Plant samples were air-dried and grain threshed from stover. Grain was weighed and sampled for water content determination. Since 1998, both corn and soybean grain were harvested with a plot combine to determine yield. Three central rows of each plot were sampled. All yield data were adjusted to $155 \mathrm{~g}^{-1} \mathrm{~kg}^{-1}$ for corn and $130 \mathrm{~g}^{-1} \mathrm{~kg}^{-1}$ for soybean.

Precipitation use efficiency was determined by dividing grain yield by annual precipitation (1 October to 30 September) and expressed as kilograms per hectare per centimeter.

Data were analyzed using a split plot in time and space analysis of variance as calculated by SAS PROC MIXED (Littell et al., 1996). Years were considered as split plots in time and a random effect. Block, tillage, and rotation effects were considered fixed in determining the expected mean squares and appropriate $F$ tests in the analysis of variance. Residuals were similar for all tillage and rotation treatments for both the corn and soybean yields. Alpha $=0.05$ was used in this study to declare effects or differences significant, unless stated otherwise.

To assess the influence of weather during different parts of the season on productivity, correlations were calculated between grain yield and mean air temperature and total pre-

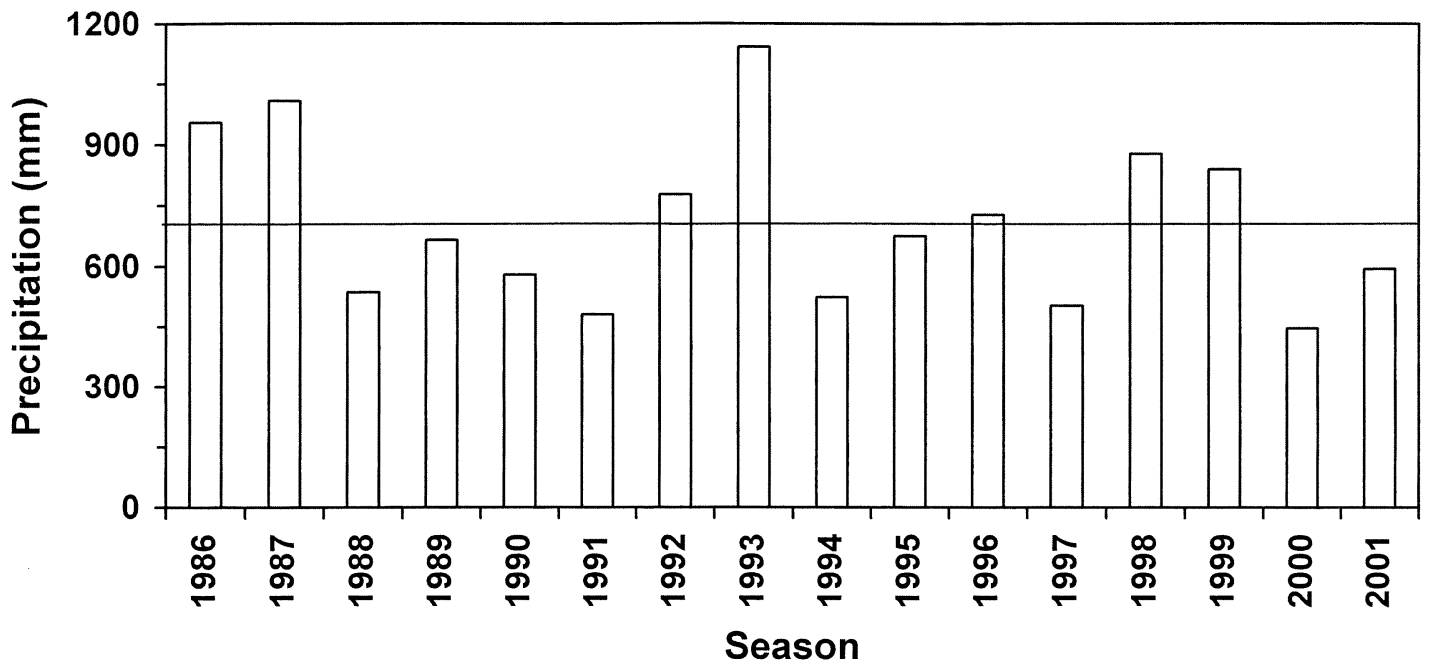

Fig. 1. Seasonal (1 October-30 September) precipitation at Rogers Memorial Farm, 1986 to 2001. The solid line is the average seasonal precipitation during the period 1986 to 2001. 


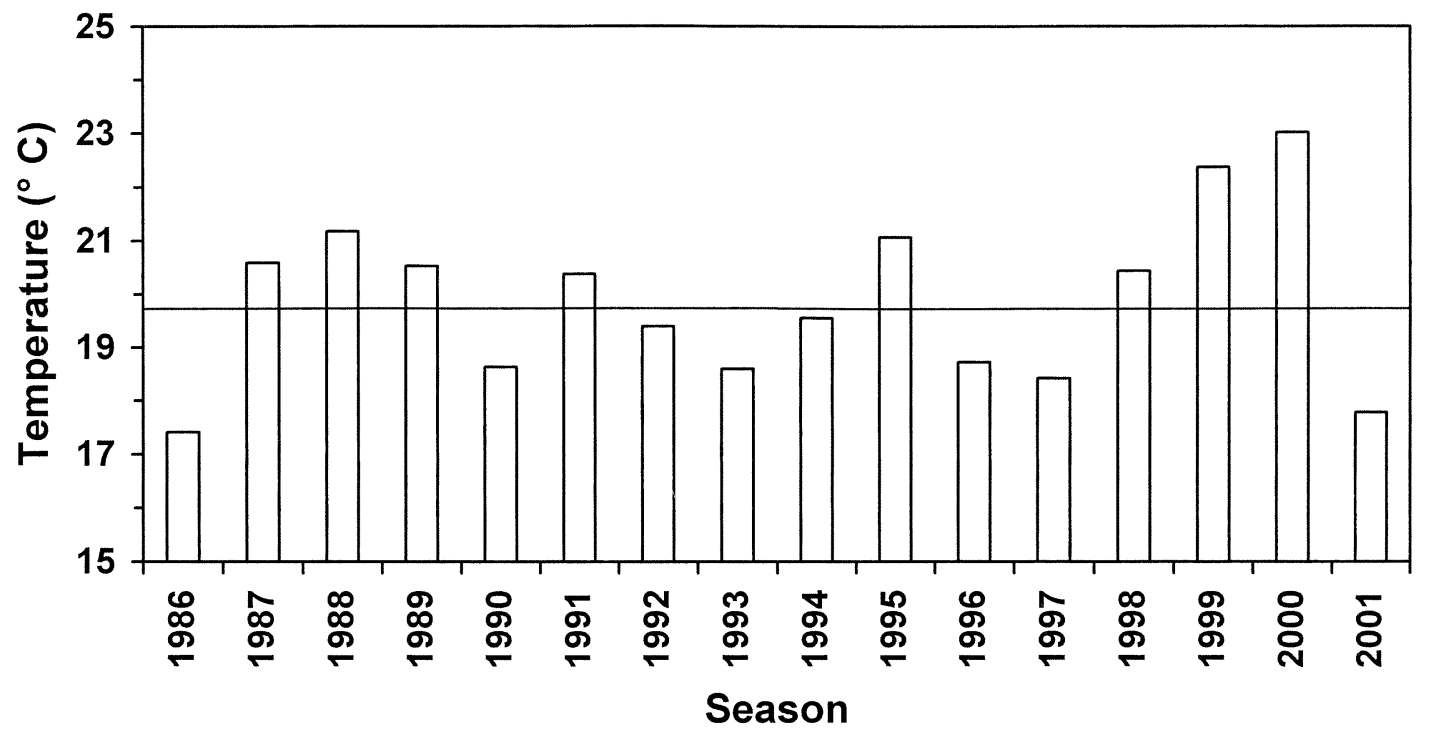

Fig. 2. Seasonal (1 October-30 September) mean air temperature at Rogers Memorial Farm, 1986 to 2001. The solid line is the average seasonal temperature during the period 1986 to 2001.

cipitation of weekly intervals over each season (1 October through 30 September). Weekly intervals with high correlations to grain yield tended to cluster, but the clusters were not consistent between air temperature and precipitation. Intervals with significant ( $p<0.05$ unless indicated otherwise) correlations with grain yield are reported. Results of these analyses are reported as yield response (increase or decrease) to temperature and precipitation. When we state, for example, that yield was less with high temperature for a specific period, we are comparing temperature and the yield response for the specific year to the average temperature for the duration of the study. Stated in other terms, if for the specified period, a negative correlation occurred between grain yield and temperature, this means that greater-than-average yields occurred in years when temperature for the period was less than average. No specific value can be assigned to high or low temperature or precipitation, the specific values differed for each period and each comparison. Even though specific values cannot be stated, the significant correlations indicate that the relative relationship occurred with a frequency greater than can be attributed to chance.

When treatment $\times$ environment (year or site) interactions are significant, the stability model of Eberhart and Russell (1966) is a tool often used by crop breeders, geneticists, and agronomists for further analysis (Lin et al., 1986; Mekbib, 2002). With this model, treatment yield is regressed (linearly) on an environmental index. Eberhart and Russell (1966) stated, "An index independent of the experimental varieties (treatments) and obtained from environmental factors such as rainfall, tem- perature, and soil fertility would be desirable." Unfortunately, an independent environmental index describing the yield potential of each environment has been difficult to construct given the variation in weather, edaphic, biotic, and management characteristics for the duration of the season and the interactions of these characteristics on crop performance. In the absence of such an independent index, Eberhart and Russell (1966) suggested that a surrogate environmental index can be composed of the trial means from the range of environments over which the experiment was conducted, thereby quantifying the production potential for each environment in terms of grain yield. This surrogate environmental index has been widely used to execute stability analyses (Saeed et al., 1987; Boman et al., 1997). For our analyses, the environmental index was composed of the annual mean yield for the entire experiment (mean of all 12 treatment combinations for each crop). Regressing the treatment means for each environment on the environmental index gave a regression coefficient $(\beta)$, which is a measure of a treatment's general responsiveness to the environment, and deviations from regression $\left(1-r^{2}\right)$ and standard errors of slope, which are estimates that measure a treatment's specific response to environmental conditions.

It is traditional to report and discuss the interactions before presenting the main effects in scientific papers. In this paper, we deviate from this mold and present the reader a general overview of the main effects before dissecting the interactions. Therefore, for both corn and soybean, we present a brief summary for the main effect before using the Eberhart and Russell (1966) stability analysis and regression analysis of

Table 1. Analysis of variance for corn and soybean yield over $16 \mathrm{yr}$ of tillage and crop sequence (rotation) treatments at the Rogers Memorial Farm.

\begin{tabular}{|c|c|c|c|c|c|c|c|c|}
\hline \multirow[b]{3}{*}{ Sources of variation } & \multicolumn{4}{|c|}{ Corn } & \multicolumn{4}{|c|}{ Soybean } \\
\hline & \multicolumn{2}{|c|}{ Degrees of freedom } & \multirow[b]{2}{*}{$F$ value } & \multirow[b]{2}{*}{$\boldsymbol{P}>\boldsymbol{F}$} & \multicolumn{2}{|c|}{ Degrees of freedom } & \multirow[b]{2}{*}{$F$ value } & \multirow[b]{2}{*}{$\boldsymbol{P}>\boldsymbol{F}$} \\
\hline & Numerator & Denominator $\dagger$ & & & Numerator & Denominator $\dagger$ & & \\
\hline Year (Y) & 15 & 890 & 447.3 & $<\mathbf{0 . 0 0 1}$ & 15 & 880 & 133.1 & $<\mathbf{0 . 0 0 1}$ \\
\hline Tillage (T) & 5 & 80.2 & 2.79 & 0.023 & 5 & 72.7 & 0.2 & 0.967 \\
\hline $\mathbf{T} \times \mathbf{Y}$ & 75 & 892 & 2.48 & $<\mathbf{0 . 0 0 1}$ & 75 & 879 & 2.2 & $<\mathbf{0 . 0 0 1}$ \\
\hline Rotation (R) & 1 & 80.2 & 182.6 & $<\mathbf{0 . 0 0 1}$ & 1 & 72.7 & 41.5 & $<\mathbf{0 . 0 0 1}$ \\
\hline $\mathbf{T} \times \mathbf{R}$ & 5 & 80.2 & 0.5 & 0.799 & 5 & 72.7 & 0.3 & $\mathbf{0 . 9 3 0}$ \\
\hline $\mathbf{R} \times \mathbf{Y}$ & 15 & 890 & 18.3 & $<\mathbf{0 . 0 0 1}$ & 15 & 880 & 6.3 & $<\mathbf{0 . 0 0 1}$ \\
\hline $\mathbf{T} \times \mathbf{R} \times \mathbf{Y}$ & 75 & 890 & 1.4 & 0.025 & 75 & 879 & 0.68 & 0.983 \\
\hline
\end{tabular}

$\uparrow$ Determined by the Kenward Rogers method in PROC Mixed (Littell et al., 1996). 
Table 2. Corn yield over 16 yr for six tillage and two crop sequences at the Rogers Memorial Farm near Lincoln, NE. $\dagger$

\begin{tabular}{|c|c|c|c|c|c|c|c|c|c|c|c|c|c|c|c|c|c|c|c|c|c|}
\hline \multirow[b]{2}{*}{ Year } & \multicolumn{3}{|c|}{ Chisel } & \multicolumn{3}{|c|}{ Disk } & \multicolumn{3}{|c|}{ No-till } & \multicolumn{3}{|c|}{ Plow } & \multicolumn{3}{|c|}{ Ridge-till } & \multicolumn{3}{|c|}{ Subsoil } & \multicolumn{3}{|c|}{ Mean } \\
\hline & nt. $\neq$ & Rot.§ & Mean & ont. & Rot. & Iean & ont. & Rot. & Mean & Cont. & Rot. & Mean & Cont. & Rot. & Mean & Cont. & Rot. & Mean & Cont. & Rot. & Mean \\
\hline & & & & & & & & & & & & & & & & & & & & & \\
\hline 1986 & 3.43 & 3.64 & 3.53 & 2.77 & 3.32 & 3.05 & 3.27 & 3.49 & 3.38 & 3.45 & 3.99 & 3.72 & 3.25 & 3.41 & 3.33 & 2.77 & 3.24 & 3.01 & 3.15 & 3.52 & 3.34 \\
\hline & 70 & 2.91 & 2.81 & 2.63 & 3.19 & 2.91 & 1.97 & 2.55 & 2.26 & 3.22 & 3.51 & & 1.95 & 3.07 & 2.51 & 2.55 & 3.37 & & 2.50 & 3.10 & 2.80 \\
\hline 8 & 01 & 6.53 & 5.77 & 5.2 & 6.40 & 5.82 & 5.44 & 6.82 & 6.13 & 5.81 & 7.30 & & 5.11 & 6.22 & & & 6.88 & & 5.27 & 6.69 & 5.98 \\
\hline 1 & & 7.67 & 7.67 & 8.6 & 7.83 & & 7.24 & 7.6 & & 7.73 & & & & & & & & & & & 7.93 \\
\hline & & & & & & & & & & & & & & & & & & & & & 7. \\
\hline & & & & & & & & & & & & & & & & & & & & & 3.63 \\
\hline & .34 & 10.89 & 10. & 10.22 & 10.95 & 10. & 10.67 & 10.86 & 10.77 & 10.56 & 10.76 & 10. & 11.07 & 11.49 & 11.28 & 10.86 & 10.88 & 10.8 & 10.62 & 10.97 & 10.80 \\
\hline & & 6.29 & & 4.97 & & & & & & & 6.8 & & 5.76 & & & & & & 5.21 & & 5.88 \\
\hline & & .73 & & & & & 7.0 & 9.2 & & 8.57 & 10.2 & & 8.05 & 9.8 & & & & & 7.93 & & 8.87 \\
\hline & 1.73 & 4.73 & & & 4.28 & 2.94 & 2.45 & 4.8 & 3.66 & 2.36 & 5.59 & 3.97 & 3.27 & 4.8 & & 2.90 & 4.8 & & 2.38 & 4.8 & 3.62 \\
\hline 1996 & 6.77 & 9.47 & 8.12 & 8.40 & 8.82 & 8.61 & 6.86 & 8.8 & 7.86 & 7.66 & 9.74 & 8.70 & 8.56 & 9.47 & 9.0 & 8.41 & 9.44 & & 7.78 & 9.30 & 8.54 \\
\hline 1997 & 5.54 & 6.28 & & 5.63 & 6.80 & & 4.99 & 6.2 & 5.5 & 6.80 & 7.37 & 7.0 & 5.57 & 6.1 & & 5.91 & 7.22 & & 5.74 & 6.67 & 6.20 \\
\hline 1998 & 7.93 & .50 & 8.22 & 7.41 & 9.54 & 8.47 & 7.40 & 9.3 & 8.3 & 8.55 & 9.9 & 9.26 & 8.23 & 8.21 & 8.2 & 8.27 & 9.54 & 8.9 & 7.96 & 9.18 & 8.57 \\
\hline 1999 & 6.02 & 8.19 & & 5.56 & 8.15 & 6.85 & 6.41 & 8.53 & 7.4 & 7.06 & 8.04 & 7.55 & 6.47 & 8.49 & & 6.03 & 8.73 & 7.3 & 6.26 & 8.35 & 7.31 \\
\hline 2000 & & 6.02 & & & & & 6.36 & & & 4.92 & 4.5 & & 6.17 & 6.1 & & 6.76 & 6.16 & & 6.23 & 6.0 & 6.12 \\
\hline 001 & & & & & 7.06 & & 5.7 & 6.28 & & 5.70 & 7. & & & & & 6.19 & 7.7 & 6. & 5.86 & 6.98 & 6.42 \\
\hline Mean & 5.68 & 6.99 & 6.34 & 5.77 & 7.07 & 6.42 & 5.44 & 6.97 & 6.20 & 6.19 & 7.31 & 6.75 & 5.94 & 7.03 & 6.49 & 5.96 & 7.25 & 6.61 & 5.83 & 7.10 & 6.47 \\
\hline
\end{tabular}

$\dagger \mathrm{SE}$ to compare rotation means $=0.058 \mathrm{Mg} \mathrm{ha}^{-1}$; SE to compare tillage treatment means $=0.115 \mathrm{Mg} \mathrm{ha}^{-1}$; $\mathrm{SE}_{\text {to }}$ compare year means $=0.112 \mathrm{Mg}^{-1}$;

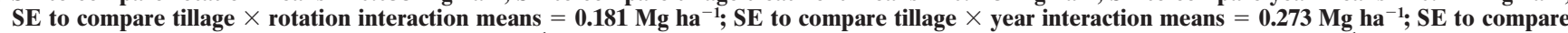
rotation $\times$ year interaction means $=0.158 \mathrm{Mg} \mathrm{ha}^{-1}$; SE to compare tillage $\times$ rotation $\times$ year interaction means $=0.386 \mathrm{Mg}^{-1}$.

† Cont., continuous cropping system.

$\S$ Rot., rotated cropping system.

weekly temperature and precipitation on grain yield to examine interactions. We feel this approach improves presentation of outcomes from this study.

\section{RESULTS AND DISCUSSION}

Seasonal (October-September) total precipitation, and its distribution, varied greatly over the $16 \mathrm{yr}$ of study (Fig. 1). The greatest precipitation occurred during the 1992-1993 season (the 1993 crop, $1142 \mathrm{~mm}$ ); the least occurred during the 1999-2000 season (the 2000 crop, $446 \mathrm{~mm}$ ). The average seasonal precipitation for the 16season period was $708 \mathrm{~mm}$. March was the driest month over the duration of the study with an average of $51 \mathrm{~mm}$ of precipitation but ranged from $0(1989,1994$, and 2001) to $75(1998) \mathrm{cm}$. June was the wettest month with an average precipitation $113 \mathrm{~mm}$ but ranged from 25 (1988) to $187(1998) \mathrm{cm}$. Seasonal average temperature for the duration of the study was $19.9^{\circ} \mathrm{C}$ (Fig. 2). The 1999-2000 season was the warmest with an average temperature of $23.0^{\circ} \mathrm{C}$. The coolest season was $1985-1986$ with an average temperature of $17.4^{\circ} \mathrm{C}$.

\section{Corn Yield}

Tillage, rotation, and year effects, and their two- and three-way interactions, except tillage $\times$ rotation, were significant for corn yield (Table 1). Mean grain yield for the continuous corn treatment was $5.83 \mathrm{Mg} \mathrm{ha}^{-1}$ for the period 1986 through 2001 (Table 2); annual mean yield ranged from 2.38 to $10.62 \mathrm{Mg} \mathrm{ha}^{-1}$. For the corn rotated with soybean, mean grain yield was $7.10 \mathrm{Mg}$ $\mathrm{ha}^{-1}$ over the 16-yr period of study (Table 2); annual mean yield for rotated corn ranged from 3.10 to 10.97 $\mathrm{Mg} \mathrm{ha}^{-1}$. The significant tillage effect for corn occurred because yield with the no-till treatment was less $(6.20$ $\mathrm{Mg} \mathrm{ha}^{-1}$ ) than with plow (6.75 $\mathrm{Mg} \mathrm{ha}^{-1}$; Table 2). The other tillage treatments had intermediate, and statistically similar, mean yields (chisel, 6.34 $\mathrm{Mg} \mathrm{ha}^{-1}$; disk, 6.42 $\mathrm{Mg} \mathrm{ha}^{-1}$; ridge-till, $6.49 \mathrm{Mg} \mathrm{ha}^{-1}$; and subsoil, 6.61

Table 3. Correlation coefficients $(r)$ between corn and soybean grain yield and mean air temperature and total precipitation for specific periods during the season.

\begin{tabular}{|c|c|c|c|c|}
\hline & \multicolumn{2}{|c|}{ Temperature } & \multicolumn{2}{|c|}{ Precipitation } \\
\hline & Correlation coefficient & Interval & Correlation coefficient & Interval \\
\hline \multicolumn{5}{|l|}{ Corn } \\
\hline Mean & -0.72 & 28 May to 19 July & $\begin{array}{l}-0.60 \\
0.45 \dagger\end{array}$ & $\begin{array}{l}26 \text { Feb. to } 13 \text { May } \\
23 \text { July to } 9 \text { Sept. }\end{array}$ \\
\hline Continuous mean & -0.72 & 28 May to 19 July & $\begin{array}{r}-0.63 \\
0.44 \dagger\end{array}$ & $\begin{array}{l}26 \text { Feb. to } 13 \text { May } \\
23 \text { July to } 9 \text { Sept. }\end{array}$ \\
\hline Rotation mean & -0.69 & 28 May to 19 July & $\begin{array}{r}-0.55 \\
0.44 \dagger\end{array}$ & $\begin{array}{l}26 \text { Feb. to } 13 \text { May } \\
23 \text { July to } 9 \text { Sept. }\end{array}$ \\
\hline Plow-no-till & $-\mathbf{0 . 5 3}$ & 19 March to 10 June & $0.43 \dagger$ & 9 July to 5 Aug. \\
\hline Continuous, plow-no-till & -0.53 & 19 March to 10 June & $0.45 \dagger$ & 9 July to 5 Aug. \\
\hline Rotation-continuous & $-0.49 \dagger$ & 26 March to 13 May & $\mathbf{N S}+$ & - \\
\hline \multicolumn{5}{|l|}{ Soybean } \\
\hline Mean & -0.71 & 23 July to 12 Aug. & NS & - \\
\hline Plow mean & -0.78 & 23 July to 12 Aug. & NS & - \\
\hline No-till mean & -0.61 & 23 July to 12 Aug. & NS & - \\
\hline Plow-no-till & -0.51 & 19 March to 10 June & 0.55 & 9 July to 5 Aug. \\
\hline
\end{tabular}

+ Significant at $p<0.10$.

+ Not significant at $p<0.05$. 

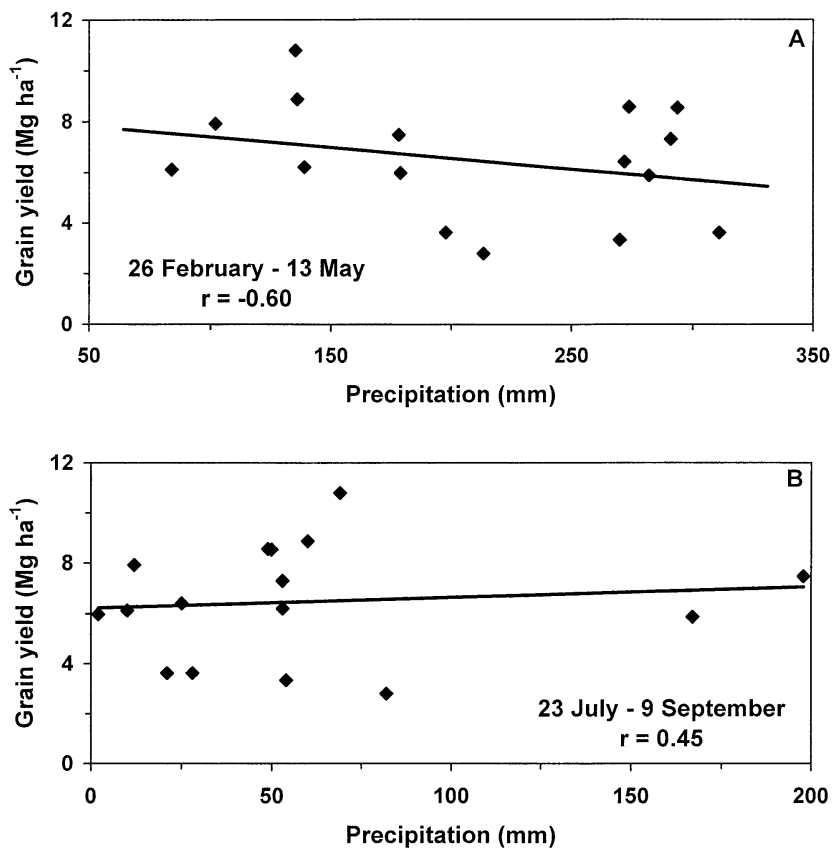

Fig. 3. Relationship between total precipitation for the intervals $(A)$ 26 February to 13 May and (B) 23 July to 9 September and corn grain yield for 1986 to 2001 .

$\mathrm{Mg} \mathrm{ha}{ }^{-1}$; Table 2). Yields are often less with no-till compared with tilled soil in more northerly latitudes, but greater yields with no-till are common (Dickey et al., 1994) although not universal (Wilhelm et al., 1987) in the latitudes of southeast Nebraska.

Annual corn yield was less when temperature from 28 May through 19 July was high $(r=-0.72$; Table 3$)$, agreeing with other results from eastern Nebraska (Yamoah et al., 1998). Annual corn yield was negatively correlated with rainfall from 26 February through 13 May ( $r=-0.60$; Table 3 and Fig. 3A). Corn yield was positively related to rainfall from 23 July through 9 September $(r=0.45, p<0.1$; Table 3 and Fig. 3B). Yamoah et al. (2000) found that corn yield in northeast Nebraska was positively related to an index value for precipitation for the 12 -mo period preceding planting in a curvilinear relationship, but this relationship did not occur in the current study.

Mean precipitation use efficiency was 93.0 (annual precipitation use efficiency ranged from 29.3-142.1) kg $\mathrm{ha}^{-1} \mathrm{~cm}^{-1}$ for continuous corn and 114.7 (annual precipitation use efficiency ranged from 36.2-170.2) $\mathrm{kg} \mathrm{ha}^{-1}$ $\mathrm{cm}^{-1}$ for corn following soybean. These values of precipitation use efficiency, as well as the yields reported above, were similar to those in another study conducted in eastern Nebraska (Peterson and Varvel, 1989a). In that study, mean yields were 5.5 and $7.6 \mathrm{Mg} \mathrm{ha}^{-1}$ for continuous and rotated corn respectively, and the means for precipitation use efficiency were 83.6 and $101.8 \mathrm{~kg} \mathrm{ha}^{-1}$ $\mathrm{cm}^{-1}$ for continuous corn and for corn following soybean, respectively (Varvel, 1994).

The rotation $\times$ year interaction was significant for corn yields (Table 1). The fitting process associated with the Eberhart-Russell stability analysis resulted in lines with similar slopes (i.e., lines were parallel) when the observed yield data for rotated and continuous corn were regressed on the environmental index (Table 4). A greater rotation effect was associated with lower spring temperatures (from 26 March through 13 May; $r=$ $-0.49, p=0.056$; Table 3 ), possibly because of less mineralization of nutrients (Linn and Doran, 1984) under cooler soil conditions.

Corn yield was generally less in odd- than in evennumbered years with a mean difference of $1.9 \mathrm{Mg} \mathrm{ha}^{-1}$ $(p=0.065)$; presumably this was a coincidence associated with the fact that mean July temperature was $1.7^{\circ} \mathrm{C}$ greater in odd years than the even year $(p=0.052)$ and not an inherent difference in basic productivity of the plots in which corn is grown during odd and even years in the 2-yr rotation because rotation treatments were randomly assigned to subplots within each tillage treatment in this experiment with a split-plot treatment arrangement.

The tillage $\times$ year interaction (Table 1 ) was not explained by regressing treatment means on the environmental index (Table 4). The relatively low $r^{2}$ value for the plow $\left(r^{2}=0.93\right)$, continuous corn treatment was because of a major negative deviation from the regression line in 2000 , but this was not explained by the weekly weather data analysis. Grain yield with the notill treatment was less than for the plow treatment with cooler weather from 19 March through 10 June $(r=$ $-0.53, p=0.036$; Table 3). Early-season soil tempera-

Table 4. The interaction effects of tillage system on continuous (cont.) and rotated (rot.) corn yield as illustrated by the regression of annual treatment means on an environmental index composed of the annual mean yields.

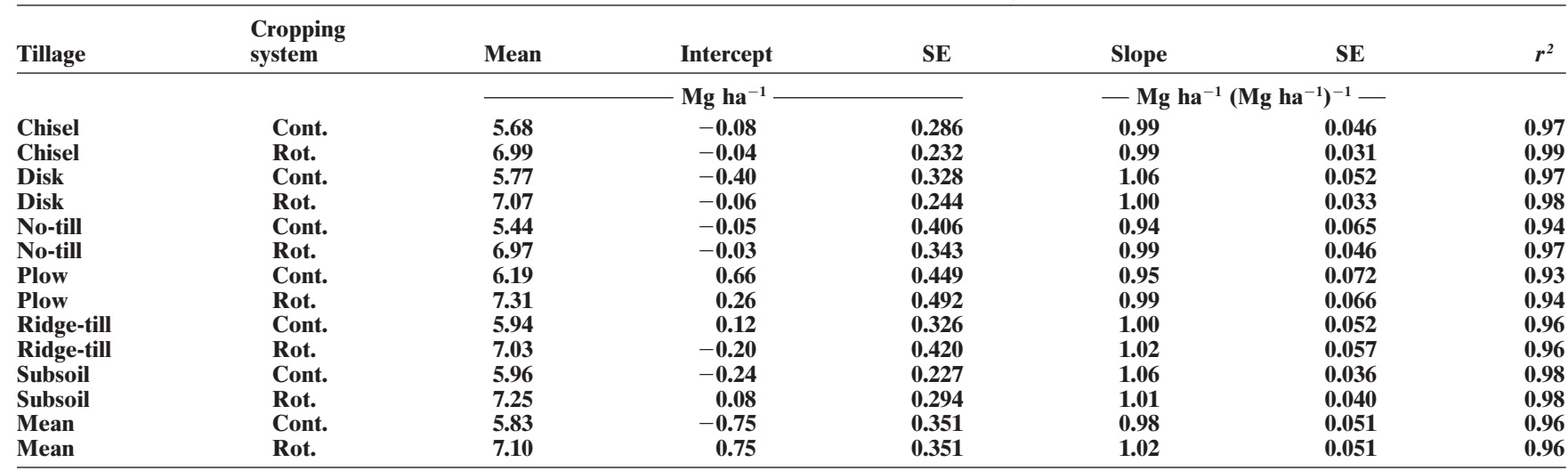


Table 5. Soybean yield over 16 yr for six tillage and two crop sequences at the Rogers Memorial Farm near Lincoln, NE. $\dagger$

\begin{tabular}{|c|c|c|c|c|c|c|c|c|c|c|c|c|c|c|c|c|c|c|c|c|c|}
\hline \multirow[b]{2}{*}{ Year } & \multicolumn{3}{|c|}{ Chisel } & \multicolumn{3}{|c|}{ Disk } & \multicolumn{3}{|c|}{ No-till } & \multicolumn{3}{|c|}{ Plow } & \multicolumn{3}{|c|}{ Ridge-till } & \multicolumn{3}{|c|}{ Subsoil } & \multicolumn{3}{|c|}{ Mean } \\
\hline & Cont. $\neq$ & Rot.§ & Mean & Cont. & Rot. & Mean & Cont. & Rot. & Mean & Cont. & Rot. & Mean & Cont. & Rot. & Mean & Cont. & Rot. & Mean & Cont. & Rot. & Mean \\
\hline & & & & & & & & & & & & & & & & & & & & & \\
\hline 1986 & 3.37 & 3.69 & 3.53 & 3.55 & 4.06 & 3.80 & 3.57 & 3.99 & 3.78 & 3.51 & 4.10 & 3.80 & 3.57 & 3.90 & 3.74 & 3.54 & 4.31 & 3.93 & 3.52 & 4.01 & 3.76 \\
\hline 1987 & .38 & 2.28 & 2.33 & 2.24 & 2.41 & 2.32 & 2.27 & 2.43 & 2.35 & 2.41 & 2.63 & & 2.03 & 2.11 & 2.07 & 2.28 & 2.18 & 2.2 & 2.27 & 2.34 & 2.30 \\
\hline 1988 & 2.77 & 2.98 & 2.88 & 2.71 & 2.92 & 2.82 & 2.84 & 2.47 & 2.66 & 2.46 & 2.57 & 2.51 & 2.45 & 3.09 & 2.77 & 2.54 & 2.95 & 2.74 & 2.63 & 2.83 & 2.73 \\
\hline 1989 & 1.70 & 2.34 & 2.02 & 1.87 & 2.06 & 1.96 & 1.91 & 2.05 & 1.98 & 2.13 & 2.27 & 2.20 & 1.80 & 2.02 & 1.91 & 1.79 & 1.92 & 1.85 & 1.8 & 2.11 & 1.99 \\
\hline 1990 & 2.31 & 1.88 & 2.09 & 1.71 & 1.80 & 1.76 & & 1.34 & 1.34 & 2.12 & 1.93 & & & 2.10 & & 2.17 & 1.77 & & & 1.80 & 1.86 \\
\hline 199 & & & & & 2.18 & & & & & & 2.2 & & & & & & 2. & & & 2.2 & 2.22 \\
\hline 199 & & & & & 2.91 & & & & & & & & & & & & & & & 97 & 3.0 \\
\hline & & & & & & & & & & & & & & & & & & & & & \\
\hline & & & & & & & & & & & & & & & & & & & & & \\
\hline & & & & & & & & & & & & & & & & & & & & & 1.52 \\
\hline 99 & 2.26 & 2.90 & & & 2.82 & 2.60 & & & & 2.65 & & & & 2.7 & 2.3 & 2.34 & 2.8 & & & 2.83 & 2.53 \\
\hline 0 & 2.32 & 2.64 & 2.48 & 2.27 & 2.55 & 2.41 & 2.33 & 2.73 & 2.53 & 2.52 & 2.87 & 2.6 & 2.05 & 2.5 & 2.28 & 2.40 & 2.6 & 2.5 & 2.31 & 2.67 & 2.49 \\
\hline 1998 & 2.93 & 2.98 & 2.96 & 2.92 & 3.04 & 2.98 & 3.19 & 3.21 & 3.20 & 3.17 & 2.74 & 2.96 & 3.09 & 3.31 & 3.20 & 2.86 & 3.16 & 3.0 & 3.03 & 3.07 & 3.05 \\
\hline 1999 & 2.59 & 2.85 & 2.72 & 2.46 & 2.83 & 2.65 & 3.02 & 3.13 & 3.07 & 2.60 & 3.11 & 2.86 & 2.56 & 2.84 & 2.70 & 2.68 & 2.78 & 2.73 & 2.65 & 2.92 & 2.79 \\
\hline 2000 & 1.32 & 2.25 & 1.78 & 1.35 & 2.06 & 1.71 & 1.73 & 2.61 & 2.17 & 1.00 & 1.38 & 1.19 & 1.16 & 1.99 & 1.58 & 1.09 & 2.14 & 1.61 & 1.27 & 2.07 & 1.67 \\
\hline 2001 & 2.22 & 2.52 & 2.37 & 2.04 & 2.57 & 2.31 & 2.20 & 2.57 & 2.38 & 2.28 & 2.58 & 2.43 & 2.04 & 2.40 & 2.22 & 2.36 & 2.49 & 2.42 & 2.19 & 2.52 & 2.36 \\
\hline Mean & 2.33 & 2.58 & 2.46 & 2.35 & 2.58 & 2.46 & 2.37 & 2.52 & 2.45 & 2.37 & 2.59 & 2.48 & 2.30 & 2.60 & 2.45 & 2.36 & 2.59 & 2.48 & 2.35 & 2.58 & 2.46 \\
\hline
\end{tabular}

$\dagger \mathrm{SE}$ to compare rotation means $=0.023 \mathrm{Mg} \mathrm{ha}^{-1}$; SE to compare tillage treatment means $=0.044 \mathrm{Mg} \mathrm{ha}^{-1}$; $\mathrm{SE}_{\text {to }}$ compare year means $=0.049 \mathrm{Mg}^{-1}$; $\mathrm{SE}$ to compare tillage $\times$ rotation interaction means $=0.057 \mathrm{Mg} \mathrm{ha}^{-1}$; $\mathrm{SE}$ to compare tillage $\times$ year interaction means $=0.121 \mathrm{Mg}^{-1}$; $\mathrm{SE}$ to compare

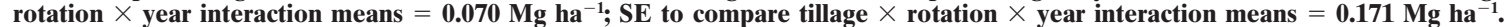

† Cont., continuous cropping system.

$\S$ Rot., rotated cropping system.

ture was not monitored throughout the duration of this study, but in 1987 , no-till soil (at $10-\mathrm{cm}$ depth) was $2^{\circ} \mathrm{C}$ cooler than plow or disk while in 1988, soil was warmer with plow than disk and no-till (Baumert-Powers, 1989). The yield advantage of plow over no-till, under the continuous corn system, was increased with greater rainfall from 9 July to 5 August ( $r=0.45, p<0.10$; Table 3 ).

The rotation $\times$ tillage interaction was not significant in this study ( $p=0.80$; Table 1$)$. In Wisconsin, Lund et al. (1993) did not observe a tillage effect on corn yield following soybean (rotation), but continuous corn yield was less with no-till than with tillage. They associated the reduced yield of no-till, continuous corn with the greater amount of crop residue and cooler soil temperature in the spring $\left(2.7^{\circ} \mathrm{C}\right.$ less). West et al. (1996) also reported less grain yield with no-till than with other tillage systems, but the yield reduction was greater with continuous corn than with corn following soybean. Swanson and Wilhelm (1996) found that different amount of spring-applied surface residue (one of the changes in the soil associated with tillage) did not affect grain yield.

The rotation $\times$ tillage $\times$ year interaction (Table 1 , $p=0.025)$ for corn yield was not because of differences in treatment response to the environment index (Table 4). When treatment means were regressed on the environmental index of annual overall mean yields, all slopes were equal to 1 . The three-way interaction effect was primarily caused by greater deviations for three treatments [continuous corn with no-till $\left(r^{2}=0.94\right)$ and both rotated $\left(r^{2}=0.94\right)$ and continuous $\left(r^{2}=0.93\right)$ corn with plow tillage] from the normal response of the other treatments to the environmental index as indicated by the lower $r^{2}$ values and greater standard error (Table 4).

\section{Soybean Yield}

The main effects of rotation and year, as well as the tillage $\times$ year and rotation $\times$ year interactions, were significant for soybean yield (Table 1). The average grain yield for soybean rotated with corn for the period 1986 through 2001 was $2.58 \mathrm{Mg} \mathrm{ha}^{-1}$, with individualyear average yields ranging from 1.56 to $4.01 \mathrm{Mg} \mathrm{ha}^{-1}$ (Table 5). For continuous soybean, the average grain yield was $2.35 \mathrm{Mg} \mathrm{ha}^{-1}$ but ranged from 1.27 to $3.52 \mathrm{Mg}$ $\mathrm{ha}^{-1}$ for individual years (Table 5). The mean yield increase associated with crop rotation $\left(0.23 \mathrm{Mg} \mathrm{ha}^{-1}\right.$; Table 5) was similar to that observed in eastern $\mathrm{Ne}$ braska by Peterson and Varvel (1989b) where the mean yields for rotated and continuous soybean were 2.7 and 2.4 $\mathrm{Mg} \mathrm{ha}^{-1}$, respectively.

Soybean yield was not significantly affected by tillage system or by the tillage $\times$ rotation interaction (Tables 1 and 5). Brown et al. (1989) also found no tillage effect on soybean yield in southeastern Iowa. The different responses of corn and soybean to tillage may be caused by the later planting dates for soybean than for corn and less impact of low early-season soil temperatures. In a comparison of tillage treatments, Dickey et al. (1994) did observe increased soybean yield with no-till in eastern Nebraska while Lund et al. (1993) reported reduced soybean yield with no-till in Wisconsin.

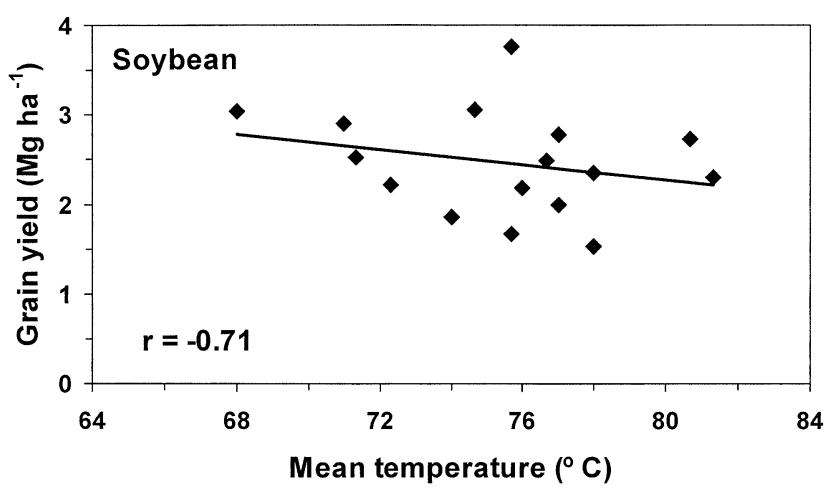

Fig. 4. Relationship between mean temperature for the interval 23 July to 12 August and soybean grain yield for 1986 to 2001. 

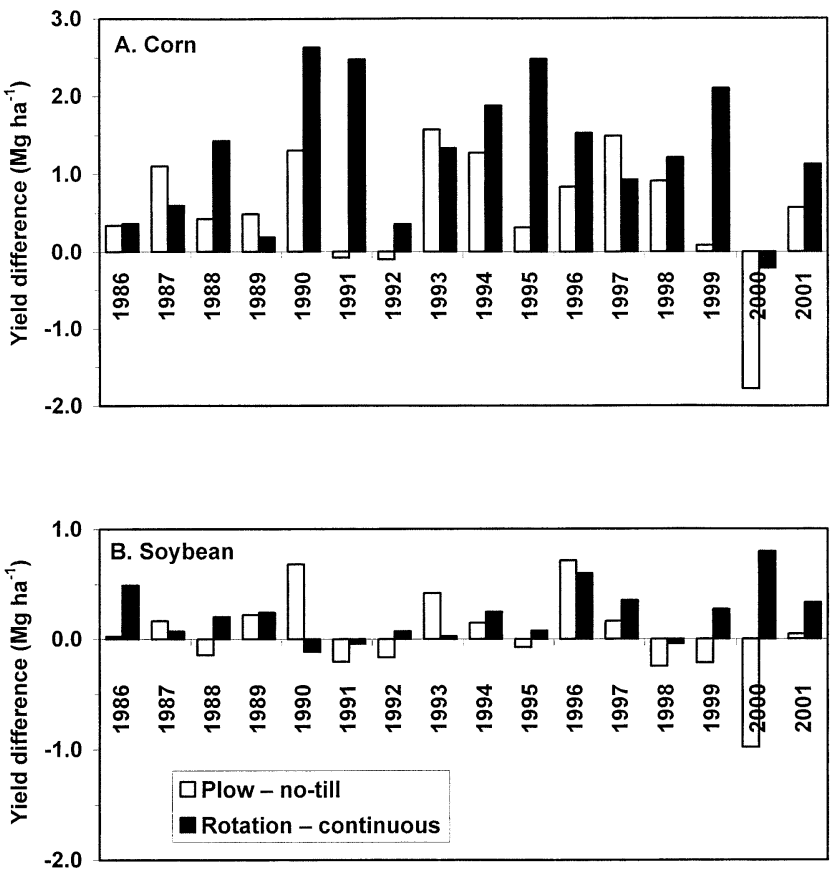

Year

Fig. 5. Yield ( $\left.\mathrm{Mg} \mathrm{ha}^{-1}\right)$ difference between (A) rotated and continuous corn or (B) soybean and plow and no-till tillage, 1986 to 2001.

Soybean yield was less with greater temperatures from 23 July to 12 August (Table 3 and Fig. 4). Yamoah et al. (1998) also found increased late-summer temperature to be negatively correlated with soybean yield, especially for continuous soybean.

The rotation $\times$ year interaction for soybean (Table 1 and Fig. 5B) was not associated with variations in rainfall or temperature (Table 3). This interaction may be of limited agronomic importance since the slopes of lines formed for each cropping system when fitted to the mean annual yield (the environmental index) were equal to one (Table 6). The interaction was presumably due to relatively greater deviation from the regression lines for rotation under no-till $\left(r^{2}=0.84\right)$ and plow $\left(r^{2}=0.86\right)$ tillage than the other tillage treatments as indicated by $r^{2}$ values (Table 6).

The significant tillage $\times$ year interaction effect was of agronomic importance (Table 1). Slopes of the regres- sion lines of soybean yield against the environmental index were $0.91 \mathrm{Mg} \mathrm{ha}^{-1}\left(\mathrm{Mg} \mathrm{ha}^{-1}\right)^{-1}$ with continuous cropping and $0.88 \mathrm{Mg} \mathrm{ha}^{-1}\left(\mathrm{Mg} \mathrm{ha}^{-1}\right)^{-1}$ with rotated cropping under the chisel treatment, indicating less response than with the other tillage treatments to change in environmental conditions (Table 6). Yield with chisel was above average when annual mean yield was low but below the mean yield when mean annual yield was high. The slopes of the environmental index vs. yield relationship for all other tillage treatments were not significantly different from 1.0. Temperature from 19 March to 10 June strongly influenced the difference in soybean yield between the plow and no-till treatments $(r=0.51$; Table 3$)$. Yield of soybean with no-till deviated most from the regression line in $4 \mathrm{yr}$, three of which (1990, 1993, and 1996) had cool springs and negative deviations, and one (2000) had a warm spring and a positive deviation (Fig. 2 and 5B). The plow treatment, on the other hand, had negative deviations in $2 \mathrm{yr}$ with warm springs and positive deviations in years with cool springs. For the plow treatments, the deviations were greatest with the corn-soybean rotation.

While soil water was not monitored continuously in this study, cumulative water use by soybean was similar (within $10 \mathrm{~mm}$ ) for plow, disk, and no-till treatments in both 1987 and 1988. In addition, leaf water potential increased and decreased more slowly (in response to rainfall and drying events, respectively) for no-till than disk and plow (Baumert-Powers, 1989). As would follow, soybean leaf water potential fluctuated more with plow than with disk or no-till. Mean precipitation use efficiency was $36.9 \mathrm{~kg} \mathrm{ha}^{-1} \mathrm{~cm}^{-1}\left(21.1-50.3 \mathrm{~kg} \mathrm{ha}^{-1} \mathrm{~cm}^{-1}\right)$ for continuous soybean and $40.7 \mathrm{~kg} \mathrm{ha}^{-1} \mathrm{~cm}^{-1}(21.3-52.2$ $\mathrm{kg} \mathrm{ha}{ }^{-1} \mathrm{~cm}^{-1}$ ) for soybean following corn.

\section{CONCLUSIONS}

Similar levels of corn and soybean productivity can be achieved with several tillage systems if well managed. Soybean yield with no-till was similar to yields with the other tillage practices. Corn yield was less with no-till than with plow tillage. The advantage of plow tillage over no-till for corn yield was greatest in years with low spring temperatures. Use of plow tillage may be

Table 6. The interaction effects of tillage system on continuous (cont.) and rotated (rot.) soybean yield as illustrated by the regression of annual treatment means on an environmental index composed of the annual mean yields.

\begin{tabular}{|c|c|c|c|c|c|c|c|}
\hline Tillage & $\begin{array}{c}\text { Cropping } \\
\text { system }\end{array}$ & Mean & Intercept & SE & Slope & SE & $r^{2}$ \\
\hline & & & $\mathbf{M g ~ h a}^{-1}$ & - & $-\mathbf{M g ~ h}$ & $-1)^{-1}-$ & \\
\hline Chisel & Cont. & 2.33 & 0.20 & 0.171 & 0.91 & 0.071 & 0.92 \\
\hline Chisel & Rot. & 2.58 & $\mathbf{0 . 3 2}$ & 0.131 & 0.88 & 0.050 & 0.96 \\
\hline Disk & Cont. & 2.35 & -0.02 & 0.135 & 1.01 & 0.056 & 0.96 \\
\hline Disk & Rot. & 2.58 & 0.02 & 0.887 & 0.99 & 0.034 & 0.98 \\
\hline No-till & Cont. & 2.37 & -0.05 & 0.284 & 1.03 & 0.84 & 0.94 \\
\hline No-till & Rot. & 2.52 & -0.25 & 0.331 & 1.08 & 0.125 & 0.84 \\
\hline Plow & Cont. & 2.37 & -0.04 & 0.225 & 1.03 & 0.093 & 0.93 \\
\hline Plow & Rot. & 2.59 & -0.09 & 0.297 & 1.04 & 0.112 & 0.86 \\
\hline Ridge-till & Cont. & 2.30 & -0.10 & 0.178 & 1.02 & 0.074 & 0.93 \\
\hline Ridge-till & Rot. & 2.60 & 0.02 & 0.200 & 0.92 & 0.076 & 0.91 \\
\hline Subsoil & Cont. & 2.36 & 0.08 & 0.137 & 0.97 & 0.057 & 0.95 \\
\hline Subsoil & Rot. & 2.59 & -0.27 & 0.117 & 1.11 & 0.044 & 0.98 \\
\hline Mean & Cont. & 2.35 & -0.07 & 0.145 & 0.98 & 0.057 & 0.95 \\
\hline Mean & Rot. & 2.58 & 0.07 & 0.145 & 1.02 & 0.057 & 0.96 \\
\hline
\end{tabular}


preferred for soils that are slow to warm or for situations where early planting is preferred. Significant gains in productivity can be achieved through rotation of corn and soybean. Greater rotation effects on corn yield were associated with cool weather in spring and with warm summers. Weather conditions and tillage practices have less influence on soybean yield than on corn yield.

\section{ACKNOWLEDGMENTS}

We gratefully acknowledge the efforts of Ms. Denise Wally to confirm the soil classification for the study site.

\section{REFERENCES}

Adee, E.A., E.S. Oplinger, and C.R. Grau. 1994. Tillage, rotation sequence, and cultivar influences on brown stem rot and soybean yield. J. Prod. Agric. 7:341-347.

Al-Darby, A.M., and B. Lowery. 1986. Evaluation of corn growth and productivity with three conservation tillage systems. Agron. J. 78:901-907.

Bakhsh, A., R.S. Kanwar, D.L. Karlen, C.A. Cambardella, T.S. Colvin, T.B. Moorman, and T.B. Bailey. 2000. Tillage and nitrogen management effects on crop yield and residual soil nitrate. Trans. ASAE 43:1589-1595.

Baumert-Powers, J. 1989. Soybean development and production under three tillage methods. M.S. thesis. University of Nebraska, Lincoln.

Boman, R.K., W.R. Raun, R.L. Westerman, and J.C. Banks. 1997. Long-term nitrogen fertilization in short-season cotton: Interpretation of agronomic characteristics using stability analysis. J. Prod. Agric. 10:580-585.

Boosalis, M.G., and B. Doupnik. 1976. Management of crop diseases in reduced tillage systems. Bull. Entomol. Soc. Am. 22:300-302.

Brown, H.J., R.M. Cruse, and T.S. Colvin. 1989. Tillage system effects on crop growth and production costs for a corn-soybean rotation. J. Prod. Agric. 2:273-279.

Cahoon, J.E., D.E. Eisenhauer, R.W. Elmore, F.W. Roeth, B. Doupnik, Jr., R.A. Selley, K. Frank, R.B. Ferguson, M. Lorenz, and L.J. Young. 1999. Corn yield response to tillage with furrow irrigation. J. Prod. Agric. 12:269-275.

Chase, C.A., and M.D. Duffy. 1991. An economic analysis of the Nashua tillage study: 1978-1987. J. Prod. Agric. 4:91-98.

Conservation Technology Information Center. 2000. Conservation tillage facts [Online]. Available at http://www.ctic.purdue.edu/ Core4/Core4Main.html (verified 5 Dec. 2003). CTIC, West Lafayette, IN.

Dick, W.A., E.L. McCoy, W.M. Edwards, and R. Lal. 1991. Continuous application of no-tillage to Ohio soils. Agron. J. 83:65-73.

Dickey, E.C., P.J. Jasa, and R.D. Grisso. 1994. Long-term tillage effects on grain yield and soil properties in a soybean/grain sorghum rotation. J. Prod. Agric. 7:465-470.

Eberhart, S.A., and W.A. Russell. 1966. Stability parameters for comparing varieties. Crop Sci. 6:36-40.

Foltz, J.C., J.G. Lee, M.A. Martin, and P.V. Preckel. 1995. Multiattribute assessment of alternative cropping systems. Am. J. Agric. Econ. 77:402-420.

Griffith, D.R., E.J. Kladivko, J.V. Mannering, T.D. West, and S.D. Parsons. 1988. Long-term tillage and rotation effects on corn growth and yield on high and low organic matter, poorly drained soils. Agron. J. 80:599-605.

Griffith, D.R., and N.C. Wollenhaupt. 1994. Crop residue manage- ment strategies for the Midwest. p. 15-36. In J.L. Hatfield and B.A. Stewart (ed.) Crop residue management. Advances in Soil Science. Lewis Publ., Boca Raton, FL.

Hesterman, O.B., F.J. Pierce, and E.C. Rossman. 1988. Performance of commercial hybrids under conventional and no-tillage systems. J. Prod. Agric. 1:202-206.

Katupitiya, A., D.E. Eisenhauer, R.B. Ferguson, R.F. Spalding, F.W. Roeth, and M.W. Bobier. 1997. Long-term tillage and crop rotation effects on residual nitrate in the crop root zone and nitrate accumulation in the intermediate vadose zone. Trans. ASAE 40:1321-1327.

Lin, C.S., M.R. Binns, and L.P. Lefkovitch. 1986. Stability analysis: Where do we stand? Crop Sci. 26:894-900.

Linn, D.M., and J.W. Doran. 1984. Aerobic and anaerobic microbial populations in no-till and plowed soils. Soil Sci. Soc. Am. J. 48: 794-799.

Littell, R.C., G.A. Milliken, W.W. Stroup, and R.D. Wolfinger. 1996. SAS system for mixed models. SAS Inst., Cary, NC.

Lund, M.G., P.R. Carter, and E.S. Oplinger. 1993. Tillage and crop rotation affect corn, soybean, and winter wheat yields. J. Prod. Agric. 6:207-213.

McCabe, D. 2002. The money helps, but. ... The Nebraska Farmer 144:25.

McIsaac, G.F., J.C. Siemens, J.W. Hummel, and A.T. Tyrrell. 1990. Economic comparisons of six corn and soybean tillage systems, two soybean spacings on three farm sizes. Appl. Eng. Agric. 6:557-564.

Mekbib, F. 2002. Simultaneous selection for high yield and stability in common bean (Phaseolis vulgaris) genotypes. J. Agric. Sci. 138: 249-253.

Peterson, T.A., and G.E. Varvel. 1989a. Crop yield as affected by rotation and nitrogen rate. III. Corn. Agron. J. 81:735-738.

Peterson, T.A., and G.E. Varvel. 1989b. Crop yield as affected by rotation and nitrogen rate. I. Soybean. Agron. J. 81:727-731.

Ritchie, S.W., J.J. Hanway, and G.O. Benson. 1986. How a corn plant develops. Spec. Rep. 48. Iowa State Univ. of Sci. and Technol. Coop. Ext. Serv., Ames.

Ritchie, S.W., J.J. Hanway, H.E. Thompson, and G.O. Benson. 1996. How a soybean plant develops. Special Report No. 53. Iowa State University of Science and Technology Cooperative Extension Service, Ames, IA.

Saeed, M., C.A. Francis, J.F. Rajewski, and J.W. Maranville. 1987. Genotype $\times$ environment interaction and stability analysis of protein and oil in grain sorghum. Crop Sci. 27:169-171.

Swanson, S.P., and W.W. Wilhelm. 1996. Planting date and residue rate effects on growth, partitioning, and yield of corn. Agron. J. 88:205-210.

Varvel, G.E. 1994. Monoculture and rotation system effects on precipitation use efficiency of corn. Agron. J. 86:204-208.

Varvel, G.E., and T.A. Peterson. 1990. Residual soil nitrogen as affected by continuous, two-year, and four-year crop rotation systems. Agron. J. 82:958-962.

West, T.D., D.R. Griffith, G.C. Steinhardt, E.J. Kladivko, and S.D. Parsons. 1996. Effect of tillage and rotation on agronomic performance of corn and soybean: Twenty-year study on dark silty clay loam soil. J. Prod. Agric. 9:241-248.

Wilhelm, W.W., J.S. Schepers, L.N. Mielke, J.W. Doran, J.R. Ellis, and W.W. Stroup. 1987. Dryland maize development and yield resulting from tillage and nitrogen fertilization practices. Soil Tillage Res. 10:167-179.

Yamoah, C.F., G.E. Varvel, C.A. Francis, and W.J. Waltman. 1998. Weather and management impact on crop yield in rotations. J. Prod. Agric. 11:219-225.

Yamoah, C.F., D.T. Walters, C.A. Shapiro, C.A. Francis, and M.J. Hayes. 2000. Standardized precipitation index and nitrogen rate effects on crop yields and risk distribution in maize. Agric. Ecosyst. Environ. 80:113-120. 